(C) 2020 Katedra Białorutenistyki UW. Wydanie w otwartym dostępie na licencji CC BY-NC-ND (https://creativecommons.org/licenses/by-nc-nd/4.0/deed.pl)

ACTA ALBARUTHENICA 20: 2020

DOI: $10.32612 /$ uw.18988091.2020.20.pp.283-286

\title{
Zofia Trzeszczkowska (Adam M-ski), Listy do Zenona Przesmyckiego z lat 1887-1901, wstęp i oprac. A. Błasińska, Wydawnictwo IBL, Warszawa 2019, 450 ss.
}

$\mathrm{y}$ кантэксце беларускае літаратуры імя Адама М-скага (сапраўднае прозвішча - Зоф'я з Манькоўскіх Тшашчкоўская, 18471911) з'явілася ў 1970-я гг., калі Уладзімір Казбярук, выявіўшы сярод карэспандэнцыі да Зянона Пшасмыцкага беларускамоўны верш паэткі Boże nas Baćka... і пераклад твора Марыі Канапніцкае U okienka (La wakonca), сярод лістоў, дасланых Феліксу Зянковічу, - пераклады тэкстаў Тэафіля Ленартовіча Kalina (Rasła kalina bujno, szyroko...) і Яна Чачота Kozak (Raście Jawor na pryhorku...), а ў рэдакцыю штотыднёвіка "Życie" пераклад верша М. Канапніцкае Jakże cię mam brać, dziewczyno... Uakże mnie ciabie dziauczуnа...), апублікаваў іх у беларускім друку1.

Дзякуючы даследнікам і перакладнікам, асобныя перыпетыі лёсу Адама М-скага, а таксама шэраг вершаў паэткі сталі вядомыя беларускаму чытачу. Беларускамоўныя тэксты Адама М-скага былі ўключаныя ў хрэстаматыі і анталогіi, польскамоўная спадчына (больш за 60 вершаў) з паралельным перакладам на беларускую мову - у падрыхтаваны Юрасём Гарбінскім і Уладзімірам Мархелем двухмоўны зборнік Цяпер і назаўсёды ${ }^{2}$.

У Польшчы творчасць Адама М-скага стала прадметам увагі навукоўцаў яшчэ ў сярэдзіне 1960-х гг. Але калі для беларускіх даследнікаў галоўнаю задачаю была папулярызацыя даробку паэта ды выяўленне ў ім беларускае складковае, дык польскія аналізавалі разнастайныя аспекты мастацкага свету, а найбольш прыцягальнае была тоеснасць дарагавіцкае аўтаркі.

Зрэшты, беларускія даследнікі, нягледзячы на тое, што палова польскамоўных тэкстаў паэткі была апублікаваная ў кнізе Цяпер і назаўсёды, фактычна не мелі магчымасці працаваць з імі: кніжка выйшла мізэрным накладам (хіба, не больш за дваццаць, а на Беларусь трапіла

1 Гл.: У. Казбярук, Беларускія вершы Адама М-скага, “Маладосць” 1971, № 12, с. 135136; У. Казбярук, Ступені росту: Беларуская літаратура канца ХIX - пачатку XX cm. $і$ т традыцыі польскіх пісьменнікаў, Мінск 1974, с. 28-33; У. Казбярук, Невядомыя беларускія вершы Зоф’і Тшашчкоўскай, “ЛіМ” 1980, 4 крас.

2 Adam M-ski (Zofia Mankowska), Dzisiaj i na wieki. Poezje. = Адам М-скі (Зоф'я Манькоўская), Цяпер і назаусёды. Паэзія, уклад. Ю. Гарбінскага, пераклады з польскай мовы І. Багдановіч, У. Мархеля, С. Мінскевіча, Інстытут Славістыкі ПАН; Інстытут літаратуры ім. Я.Купалы НАН РБ, Warszawa - Minsk = Варшава - Мінск 2004. 
нязначная з іх колькасць - здаецца, толькі перакладнікі атрымалі ад укладальніка "аўтарскія" асобнікі). У Сеціве электроннага варыянта кнігі няма. Да нядаўняга часу большасць прыжыццёвых публікацый Адама М-скага таксама была недаступнаю: ix не было ў Сеціве, а беларускія бібліятэкі не маюць поўных камплектаў польскіх перыядычных выданняў XIX - пачатку XX стагоддзя.

Не лепш справа выглядала і з лістамі паэткі: па даўняй савецкай традыцыі навуковец, характарызуючы выяўленыя ў архівах матэрыялы, звыкла не інфармаваў пра дакладнае іх месцазнаходжанне; цытуючы - к лепшым выпадку называў дату таго ці іншага ліста. Наколькі нам вядома, фотакопіі ці мікрафільмы карэспандэнцыі Адама Мскага на Беларусі адсутнічаюць.

А таму падрыхтаваная і выдадзеная ў 2019 г. Аляксандраю Бласінскаю кніга Zofia Trzeszczkowska (Adam M-ski). Listy do Zenona Przesmyckiego z lat 1887-1901 пэўным чынам можа кампенсаваць недахоп крыніцаў і вывесці навуковыя даследаванні на новы ўзровень.

Выданне складаецца з Прадмовы А. Бласінскае (Zofia Trzeszczkowska i jej listy do Zenona Przesmyckiego s. 5-43), уласна карэспандэнцыі (усяго - 98 допісаў, часта вялікага аб'ёму - да 10 старонак) Адама Мскага (Listy, s. 45-418) з грунтоўным каментаром укладальніцы, спісу арыгінальных твораў з пазначэннем часу і месца публікацыі (ці архіўнага адрасу, калі тэкст не друкаваўся), а таксама спісу перакладзеных паэткаю з французскае, партугальскае, ангельскае і чэшскае моваў твораў 17 аўтараў (Wykaz utworów i przekładów Zofii Trzeszczkowskiej, s. 419-428). Цікавым падаецца і дадатак (Aneks, s. 429-432), дзе змешчаныя два дакументы: копія метрычнае выпіскі пра нараджэнне і хрост Зоф’і Марыі Манькоўскае і копія метрычнае выпіскі пра шлюб Вацлава Тшашчкоўскага і Зоф'і Манькоўскае. Яны, дарэчы, выяўленыя А. Бласінскаю ў НГАБ у Мінску.

Прадмова да публікацыі лістоў Адама М-скага ў сваю чагу складаецца з трох частак: 1. Rys biograficzny, 2. Relacje z Przesmyckim: Listy jako studium osobowości, 3. Ważniejsza twórczość oryginalna i przekładowa $w$ świetle listów.

Заўважым, што біяграфічны нарыс пра Зоф’ю з Манькоўскіх Тшашчкоўскую атрымаўся ў А. Бласінскае дастаткова лаканічны, але змястоўны. Выяўленыя дакументы дазволілі даследніцы ўдакладніць дзве важныя даты ў жыцці паэткі - дзень нараджэння ("urodziła się 29 listopada 1847 roku w Dorohowicy w pobliżu Kopyla") і дзень шлюбу ("w wieku dziewiętnastu lat, 26 listopada 1866 w Nieświeżu, panna Mańkowska poślubiła Wacława ?rzeszczkowskiego, Polaka").

Што датычыць дня нараджэння, дык выяўленае У. Мархелем у 2006 г. надмагілле фіксуе крыху іншую дату - 26.11.1847 г. Каму даць веры?

Лічым патрэбным звярнуць увагу яшчэ на адно пытаннепраблему: як перадаваць прозвішча паэткі ў навуковых публікацыях. 
Так, сапраўды, з 1866 г. яна афіцыйна называлася Зоф'яю Тшашчкоўскаю. Але як паэтка і перакладніца - яна адно Адам М-скі, як аўтарка лістоў да 3. Пшасмыцкага - яна зноў жа Адам М-скі (Адам Манькоўскі, Адам М., А. М.). Ці ж ёсць падставы называць паэтку Зоф'яю Тшашчкоўскаю? Толькі тады, калі гісторык літаратуры ігнаруе волю аўтаркі. А яна мела прычыны (А. Бласінская называе іх) хаваць і сваё імя, і сваю тоеснасць. Дапускаем, што паэтка дала дазвол (хоць гэтага магло і не быць) сваім блізкім, каб пасля ейнае смерці яны адкрылі таямніцу. Вельмі верагодна, што зрабіла гэта паэтка і стрыечная сястра Альдона Раецкая (1853-1922): спачатку паведаміла пра смерць уладальніцы Дарагавіцы ў штотыднёвікі "Świat”, “马ygodnik Illustrowany" i "Bluszcz", а пасля загадала выбіць на надмагіллі: "Zofja z Mańkowskich / ?rzeszczkowska / Poetka Adam M-ski. / Ur. 1847 26/国 † 24/I0 1911 / w Dorohowicy. / Może wiatr pieśni rozniesie po świecie / Pieśń serca, które czuło tak gorąco".

Няраз у сваім выданні А. Бласінская закранае тэму разводу сужэнцаў Тшашчкоўскіх. I робіць гэта - скажам так - традыцыйна. Бо амаль ва ўсіх публікацыях пра Адама М-скага нязменна падкрэсліваецца, што ладу ў сям'і Тшашчкоўскіх не былоз. Патрыятызм маладое жонкі, маўляў, мусіў уступіць у канфлікт з лаялізмам мужа, расейскага афіцэра (у 1866 г. - паручнік, а ў 1881 - ужо падпалкоўнік). Аднак на самай справе мы амаль нічога не ведаем пра сапраўдны стан рэчаў. Чаму, уласна, 19-гадовая 3. Манькоўская, атрымаўшы патрыятычнае выхаванне дома і у “школе” Францішкі Клячкоўскае ў Вільні, пайшла замуж за чалавека, гадоў на 15 за яе старэйшага, які з 1855 г. (пасля заканчэння Канстанцінаўскага кадэцкага корпусу “выпущен в 3-ю полевую артиллерийскую бригаду”), трэба думаць, сумленна служыў цару? Прынамсі, на бок паўстанцаў у 1863 г. ён, здаецца, не пераходзіў. Ці мы тут чаго не ведаем? Звернем увагу яшчэ на адну невялікую дэталь. Штотыднёвік "Prawda” ў 1897 г. публікуе спіс асобаў, якія даслалі ахвяраванні на помнік Адаму Міцкевічу ў Варшаве: "Z Dorohowicy (g. Mińska): Michalina Mańkowska - 3 rs., Wacław ?rzeszczkowski - 5 rs., Adam M-ski - 5 rs.". Ці азначае гэта, што В. Тшашчкоўскі жыў у гэты час у маёнтку жонкі? Ці гэта чарговая містыфікацыя Адама М-скага?

На думку А. Бласінскае, ужо напрыканцы 1880-х гг. 3. Тшашчкоўская пачала рабіць захады, каб развесціся з мужам. А той факт, што пасля сакавіка 1891 г. яна ўжо нібыта больш не ездзіла ў Ноўгарад, можа быць сведчаннем ростані былых сужэнцаў. Аднак падобнае сцвярджэнне не мае дакументальнае базы. Нават "przygoda uczuciowa poetki" не можа адназначна служыць пацвярджэннем разводу, бо - як сама яна напіша - "właściwie i romansu nie było". Таямнічае каханне Зоф’і да нейкае асобы "z Północy" (дакладней, што з'ехала на Поўнач), лісты да якое і ад якое ("gorętsze od listów Heloizy i Abelarda") паэтка планавала выдаць

${ }^{3}$ На падставе лістоў да 3. Пшасмыцкага сцвердзіць гэта адназначна немагчыма. 
з дапамогаю 3. Пшасмыцкага і нават у часе свае хваробы збіралася яму выслаць, але ў апошнюю хвіліну нібыта спаліла, застаецца неразгаданаю загадкаю. Ці можам мы паверыць, што ейны каханы з'ехаў на Поўнач? Логіка і прыёмы містыфікацый паэткі даводзяць, што каханы “павінен” быў паехаць у адваротным кірунку, г. зн. на Поўдзень. Дык ці не быў гэтым каханым 3. Пшасмыцкі, які - як вядома - у той час пераехаў у Парыж${ }^{4}$.

Праўда, напачатку нам падавалася, што маецца больш падстаў, каб лічыць Ф. Зянковіча тою асобаю, пра якую згадвае Адам М-скі ў лісце да 3. Пшасмыцкага ад 12 лістапада 1896 г. Бо спаткаўшы былога паўстанца у 1881 г. у Ноўгарадзе, 34-гадовая Зоф’я магла захапіцца ім. I нешта падобнае сапраўды здарылася. Хоць больш падстаў казаць пра патрыятычную, а не інтымную складковую ў вектары ўплыву Ф. Зянковіча на паэтку.

А вось што да дачыненняў Зоф'і з 3. Пшасмыцкім, то менавіта ад яе сыходзілі “промні" патрыятызму; менавіта яна навучала і настаўляла маладзейшага паэта і перакладніка. Звернем таксама ўвагу на тое, як змянялася "тэмпература" лістоў Адама M-скага: ад "Szanowny Panie" да "Druhu mój dobry” i "bracie”. А што пісаў ёй 3. Пшасмыцкі? Трэба думаць, надзвычай высока ацаніў здольнасці і талент паэткі. I ці не было дастаткова гэтага, каб сэрца 40-гадовае кабеты запалілася незвычайным пачуццём, якое вылілася ў вершы U stóp ja twoich chciałbym leżeć cichy і знаменавала пачатак рамана, "якога не было".

Ускоснае сведчанне пра "раман” 3. Тшашчкоўскае і 3. Пшасмыцкага мы знаходзім на тых старонках працы даследніцы, дзе яна даволі пераканаўча даводзіць, што польскі паэт і перакладнік ведаў, хто хаваецца пад псеўданімам Адам М-скі (c. 17-19).

Кніга А. Бласінскае падрыхтаваная вельмі старанна і на высокім навуковым узроўні. Дробныя недакладнасці і памылкі (напрыклад, у датаванні асобных лістоў) мы не лічым патрэбным тут называць. Але адзін істотны, на нашую думку, недахоп павінны адзначыць. Шкада, што А. Бласінская не пажадала падаць у спісе арыгінальных твораў і перакладаў Адама М-скага пяць ягоных беларускамоўных тэкстаў. Ці ж згадка пра беларускамоўны даробак паэткі ў польскім навуковым выданні сапсуе імідж краёвае літаратуры?

Мяркуем, што кніга А. Блашчынскае з'яўляецца важнай і патрэбнай для гісторыкаў літаратуры XIX стагоддзя. Маем надзею, што і беларускія навукоўцы будуць мець мажлівасць пазнаёміцца з ёю.

Мікола Хаўстовіч m.khaustovich@uw.edu.pl

\footnotetext{
4 Больш дэталёва пра гэта і пра іншае гл. у планаваным раздзеле VII тома нашых Даследаванняў і матэрыялаў на 2021 год.
} 